\title{
Histone H2 Gene
}

National Cancer Institute

\section{Source}

National Cancer Institute. Histone H2 Gene. NCI Thesaurus. Code C154298.

A gene encoding the core histone protein histone $\mathrm{H} 2$. 